\title{
Reading as Cultural Factor of Talent Development
}

\author{
${ }^{1}$ Elena M. Shastina , ${ }^{2}$ Olga V. Shatunova , ${ }^{3}$ Tatiana F. Borodina \\ ${ }_{1,2,3}$ Kazan Federal University, Elabuga, Russia \\ Email:shastina@rambler.ru, olgashat67@mail.ru, tatjanabaschina@yandex.ru
}

\section{Received: 21st October 2017 Accepted: 16th November 2017, Published: 31st December 2017}

\begin{abstract}
The modernization of Russian education implies the trend for its humanization and humanitarization, which determines the significance of the cultural approach to the study of pedagogical problems. The purpose of this article is to describe the role of the culturological factor that promotes the revealing of children talents and creates the prerequisites for their development.

The methods of research are the generalization of advanced pedagogical experience, observation, questionnaires and conversations.

The work presents the results of the probing experiment, in which 130 teachers from the Elabuga Institute of the Kazan Federal University at the age of 25 - 79 took part. They were characterized by pronounced personal and professional qualities and the abilities that make consider them as gifted people. The experiment consisted of a survey on the author's questionnaire about the readers' activity of the respondents at different age stages of personal development, as well as on the giftedness and the influence of reading on its development.

The study proves the positive impact of reading as a culturological factor on the development of giftedness. Besides, it is concluded that people who have reached a certain stage of professional and personal development (including giftedness) are characterized by constant reading activity.

The authors put forward for a discussion of a number of questions concerning the identification of the role of reading for giftedness among the representatives of different professions and ages at different stages of physiological and personal development.
\end{abstract}

Keywords: Culturological Approach, Culturological Factor, Reading, Giftedness, Development of Giftedness

\section{Introduction}

The issue about the culturological component of education acquires a special significance in the conditions of a changing educational environment not only in our country, but throughout the world. The introduction of the Bologna education system, the development of new state standards, entailed dramatic changes in Russian education system, which affected not only the higher school, but also the basic general education aimed at the development of a modern student personality. The trend on humanization and humanitarization of education adopted in 2002 as the part of the concept of Russian education modernization, allowed a new look at the problem of cultural education in the context of cultural paradigm change. According to I.E. Vidt's opinion, "the cultural fundamentals of education presuppose the adequacy and the congruence of the existing culture-civilization" [1, p. 67] (Vidt, 2002, p.67). Russian researchers V.S. Bibler [2], A.P. Valitskaya [3], I.E. Vidt [1], E.A. Yamburg [4] and others developed the principles of culturological education, the essence of which is that the result of the correlation between education and culture as a system considered from the standpoints of synchronous and diachronic development, the prerequisites for the upbringing of a "a man of culture" are created that can comprehend a person's place in the cultural system and realize his role in its preservation and reproduction. In particular, V.S. Bibler writes that modern pedagogy is characterized by the change in the ideal of education, by its transition from the educational paradigm to the cultural creation one, from "an educated person" to a "man of culture" [2, p. 337]. A priori in the process of teaching humanitarian, artistic and natural science disciplines a general cultural training is realized, which, in addition to knowledge and skills, forms an emotional and value attitude to cultural phenomena [5, p. 329].

As you know, L.S. Vygotsky introduced the concept of "cultural development" of an individual, suggesting the creation of conditions that promote not only the physiological, but also the intellectual development of a child [6]. Naturally, the intellectual development of a child is directly related to the problem of giftedness.

In the logic of this study, the method of developmental learning $[6 ; 7]$ is of interest because it allows one to build a kind of "algorithm" of a child's cultural development - from primary school to upper school, which ideally should meet the requirements of the Federal State Educational Standard for Basic General Education (FSES BGE).

Thus, during the development of education content a culturological approach must be developed that aims to realize a humanistic attitude toward the social purpose of a man, which in its turn involves the inclusion of different structures of culture in the context of education content.

The purpose of this article is to describe the role of the culturological factor that promotes the identification of children giftedness and creates the prerequisites for its development. V.S. Yurkevich points out the need to 
change the approach to giftedness. In particular, according to the scholar's opinion the creation of a "cultural foundation" of giftedness should become, one of the priority areas of an individual intellectual development [8, p. 106].

\section{Methods}

The interest to the problem of giftedness among children and young people in psycho-pedagogical science has been growing in recent years, and the main trend of research in this area is the problem of gifted children and the features of their development identification.

Giftedness is the quality of the psyche, which determines the possibility of high result achievement in various activities. Consequently, a gifted child is a child who has bright, obvious, sometimes outstanding achievements, or has internal prerequisites for this or that kind of activity. According to the concept of the American scholar J. Renzulli, giftedness is a combination of three characteristics: intellectual abilities (exceeding an average level), creativity and perseverance (task-oriented motivation) [9]. According to the scholar's opinion, gifted children should be attributed not only to those who outperform their peers in all three main parameters, but also those who demonstrate a high level of at least one of them. In addition, this concept takes into account knowledge (erudition) and a favorable environment.

Giftedness should be regarded as a kind of dynamic characteristic. This is not a static (constant) personal indicator, but a constantly developing potential. Here we can highlight the problem of giftedness development, or, in other words, the problem of potential development concerning the personality of each child. This aspect is the most productive in terms of pedagogy, which is why it is being developed intensively in a number of pedagogical studies [10-14]. A positive moment for today is the openness of researches, reflecting the world experience of work with gifted children. Modern society, which focuses the younger generation on success, on the development of leadership qualities, puts the work with gifted children into the rank of the most important state tasks [15-17].

The development of giftedness is always the result of the complex interaction of heredity (natural makings) and social environment mediated by a child's activity (play, training, labor one). At that a special role in this is given to the child's own activity, as well as to the psychological mechanisms of a personality selfdevelopment, which are the basis for the development and the realization of his giftedness.

The variety of giftedness manifestations is its dependence on age, the organization of the educational process at school and the peculiarities of the upbringing of children in the family led to the following criteria for the determination of the types of giftedness [18]:

- in the breadth of manifestation - general and special giftedness;
- by the type of preferred activity - intellectual, academic, creative, artistic, psychomotor (sports), design, leadership (organizational), etc.;

- by the form of manifestation - obvious and hidden one (not manifested);

- by the degree of development: potential and actual giftedness;

- in terms of age features of manifestation - early giftedness and late giftedness.

Thus, giftedness is a multilateral but integral phenomenon. A gifted child has to have certain genetic predispositions, and the environment (family, school, peers, etc.) should contribute to the development of his personal qualities.

Among the main factors of giftedness development, the following ones can be identified:

- Biological: morphological, reflex, temporal, energy, genetic, etc.;

- Physical: radio stimulation, solar activity on the day of birth, "oxygen" effect, etc.;

- Social: pedagogical, family,

- culturological: literature, art.

An effective culturological factor in our case is literature as the part of world culture. Naturally, the perception of literature is directly related to the process of reading. The discussion character of the reading process essence, which in modern science is viewed from different positions - psychophysiological, psychological, psycholinguistic ones, etc. - remains beyond the scope of the article. The fact that the role of literature and reading received legislative support, having found the reflection in FSES BGE is fundamentally important. The successful development of a child's personality requires to "realize the importance of reading and studying literature for his further development." "The understanding of literature" is necessary for "cultural self-identification", since literature is one of the "ways of knowing life" and knowing yourself in this world [19] (FSES BGE, p. 9). Thus, the study of literature at school for the purpose of a "a man of culture" education should become "the way of entering culture, the cognition of its historical types, the comprehension of its types of consciousness, codes and semantic signs for a student" [20, p. 9].

Thus, V.A. Glukhova notes that the development of children is influenced by their interaction with the cultural space: home environment, enriched by cultural stimuli (books, paintings); direct communication with the artifacts of culture (joint excursions, trips); the inclusion of parents in the process of their cultural and educational level increase [21].

In order to reveal the influence of reading as a culturological factor on the development of giftedness and confirmation of the studied problem relevance, a probing experiment was conducted in which the faculty of the Elabuga Institute at the Kazan Federal 
University took part. 130 teachers at the age from 25 to 79 years were selected as the respondents, who have significant achievements in the field of professional and public activity, who display an active life position, as well as characterized by a number of clearly expressed personal qualities that relate to a certain kind of giftedness (including creative, organizational, communicative abilities, leadership qualities, cognitive activity, etc.). The experiment consisted of a survey of respondents on the author's questionnaire, consisting of closed and open questions about the reading activity of respondents at different stages of personal development, as well as about the giftedness and the influence of reading on it.

\section{Results}

The choice of a questioned group was determined by the possibility of detailed objective information obtaining about the accomplishments and personal characteristics of respondents. The group was homogeneous in order to obtain more reliable information about the representatives of a certain type of activity. Besides, we believe that only gifted individuals can become successful and deserved teachers of higher educational institutions.

First of all, it should be noted that about a third of respondents could not unequivocally answer the question whether they showed talent in childhood. Only $38 \%$ of teachers who participated in the experiment believed that they were gifted children.

The importance of reading for the development of giftedness was noted by $100 \%$ of the interviewed teachers. At that, $25 \%$ of respondents believe that the development of their giftedness was facilitated by the reading of specific works of fiction or scientific literature. If we assume that reading promotes the development of giftedness, and the subjects are gifted, then through their interrogation one can obtain information about literature, the reading of which has a favorable effect on giftedness.

In the process of analyzing the obtained data it was noted that $100 \%$ of surveyed teachers showed reading activity (we mean the reading not related to the implementation of professional functions and not aimed at the solution of professional problems) from childhood to the present. This was evidenced by detailed answers to the questions of the questionnaire. Thus, it was possible to establish that the majority of respondents $(42 \%)$ had books for children (fairy tales, short stories and stories for children) that were favorite books in childhood. According to $88 \%$ of teachers, the favorite books of their childhood have remained relevance until today (the most popular were "Robinson Crusoe" by D. Defoe, "The Adventures of Neznaika and His Friends" by Nosov and the tales of the peoples of the world).

At present, respondents, in general, prefer to read novels about love, friendship and family relationships this genre of fiction was noted by $37 \%$ of the respondents. $61 \%$ of all favorite books were written by domestic authors (the most popular are M.A. Bulgakov's "Master and Margarita", J. Austin's "Pride and Prejudice").

\section{Conclusions}

The results of the survey confirm the idea of the importance of reading both classical and modern domestic and world literature. The favorite classic writers for the respondents are L.N. Tolstoy, M.A. Bulgakov, F.M. Dostoevsky, A.S. Pushkin; The most popular contemporaries are B. Akunin, L. Ulitskaya and D. Rubina. E.M. Remark and T. Dreiser, as well as the contemporary writers P. Coelho, H. Murakami and G.G. Marquez are marked as the preferred authors of classical world literature.

\section{Summary}

Based on their own experience, the teachers who participated in the survey can recommend reading literature that promotes the overall development of an individual. The recommendations concerning the age of readers are given in Table 1.

The carried out experiment allows us to draw the following conclusions. First, reading as a culturological factor can influence the giftedness. Secondly, people who have reached a certain stage of professional and personal development (including giftedness) are characterized by constant reader activity. Thirdly, talented individuals with significant achievements are interested in the world fiction and non-fiction literature.

Table 1 - Recommendations for Reading, depending on Age Group

\begin{tabular}{|c|c|c|c|c|}
\hline $\begin{array}{l}\text { Age group of } \\
\text { readers }\end{array}$ & $\begin{array}{l}\text { Rank (by } \\
\text { reference } \\
\text { frequency) }\end{array}$ & Respondents, \% & $\begin{array}{c}\text { Recommended literature } \\
\text { genre }\end{array}$ & Most popular works \\
\hline \multirow{3}{*}{$\begin{array}{l}\text { Preschoolers and } \\
\text { pupils of lower } \\
\text { grades } \\
\text { years) }\end{array}$} & 1 & 60 & Fairy tales, tales, fantasy & \multirow{3}{*}{$\begin{array}{l}\text { Tales of the peoples of } \\
\text { the world, "The } \\
\text { Adventures } \\
\text { Neznaika and His } \\
\text { Friends" by Nosov, } \\
\text { "The Wizard of the } \\
\text { Emerald City" by A.M. } \\
\text { Volkov }\end{array}$} \\
\hline & 2 & 26 & $\begin{array}{l}\text { Short stories and stories for } \\
\text { children }\end{array}$ & \\
\hline & 3 & 5 & $\begin{array}{l}\text { Instructive parables and fables, } \\
\text { educational works }\end{array}$ & \\
\hline
\end{tabular}




\begin{tabular}{|c|c|c|c|c|}
\hline \multirow{3}{*}{$\begin{array}{l}\text { Учащиеся } \\
\text { средних классов } \\
\text { (11-15 лет) }\end{array}$} & 1 & 27 & Adventure novels and novels & \multirow{3}{*}{$\begin{array}{l}\text { "White Fang" by J. } \\
\text { London, "Robinson } \\
\text { Crusoe" by D. Defoe, } \\
\text { "Polianne" by E. Porter }\end{array}$} \\
\hline & 2 & 23 & Novels and stories for teens & \\
\hline & 3 & 16 & Science fiction & \\
\hline \multirow{3}{*}{$\begin{array}{l}\text { Students } \quad \text { of } \\
\text { middle classes } \\
(11-15 \text { years })\end{array}$} & 1 & 28 & Family novels and novels & \multirow{3}{*}{$\begin{array}{l}\text { "A dawn here are } \\
\text { quiet" by B. Vasiliev, } \\
\text { "Master and Margarita" } \\
\text { by M.A. Bulgakov, } \\
\text { "The Portrait of Dorian } \\
\text { Gray" by O. Wilde }\end{array}$} \\
\hline & 2 & 14 & Romance novels & \\
\hline & 3 & 10 & $\begin{array}{l}\text { Adventure and historical novels, } \\
\text { short stories and the stories on } \\
\text { social topics }\end{array}$ & \\
\hline \multirow[t]{3}{*}{$\begin{array}{lr}\text { Students } & \text { of } \\
\text { universities } & (18- \\
22 \text { years }) & \end{array}$} & 1 & 30 & $\begin{array}{l}\text { Social and social-psychological } \\
\text { novels, family and romantic } \\
\text { novels }\end{array}$ & \multirow{3}{*}{$\begin{array}{l}\text { "Wonderland without } \\
\text { brakes and the End of } \\
\text { the World" by H. } \\
\text { Murakami, "Medea and } \\
\text { her children" by L.E. } \\
\text { Ulitskaya, "Zuleikha } \\
\text { opens her eyes" by "G. } \\
\text { Yakhina, " Brave new } \\
\text { world" by O. Huxley }\end{array}$} \\
\hline & 2 & 12 & $\begin{array}{l}\text { Popular science and developing } \\
\text { literature }\end{array}$ & \\
\hline & 3 & 10 & $\begin{array}{l}\text { Stories and short stories on life } \\
\text { issues }\end{array}$ & \\
\hline
\end{tabular}

On the other hand, the questioning gave birth to a number of issues that require a deeper understanding:

1. Does the influence of reading on giftedness appear among the representatives of different professions and ages?

2. At what stage of physiological and personal development does reading have the greatest impact?

3. Does the reading of specific genres or works of literature influence the development of giftedness among children?

4. Does the reading of literature recommended by the interviewed teachers influence the development of giftedness among children? etc.

The empirical data obtained during the experiment confirm the urgency of the problem being developed, and the arising questions determine the need for its further and deeper study.

\section{Acknowledgements}

The work is performed according to the Russian Government Program of Competitive Growth of Kazan Federal University.

\section{References}

1. Vidt I.E. Culturological foundations of education. Tyumen: Publishing house of Tyumen State University, 2002. 164 p.

2. Bibler V.S. On the facets of the logic of culture. Moscow: Russian phenomenological society, 1997. $423 \mathrm{p}$.

3. Valitskaya A.P. "A New School in Russia: culture-making model" / ed. by prof. V.V. Makaev. SPb.: Publishing House of the Russian State Pedagogical University named after A.I. Herzen, 2005. $146 \mathrm{p}$.

4. Yamburg E.A. The contours of cultural and historical pedagogy // Pedagogy. 2001. № 1. pp. 310 .

5. Tokarev S.N. Cultural education as an aspect of cultural development // Culturological studies:
Collection of scientific works. SPb.: Publishing House of Russian State Pedagogical University named after A.I. Herzen, 2002. pp. 327-343.

6. Vygotsky L.S. Pedagogical Psychology / ed. by V.V. Davydov. M.: Pedagogika-Press, 1999. $536 \mathrm{p}$.

7. Davydov V.V. The theory of developmental learning. Moscow: INTOR, 1996. 544 p. 8. Yurkevich V.S. Gifted children: current trends and tomorrow challenges // Psychological science and education. 2011. № 4. pp. 99-108.

9. Renzulli J. S. Guiding the gifted in the pursuit of real problems: The transformed role of the teacher // The Journal of Creative Behavior. 1983. № 17 (1). P. 49-59.

10. Jeanne H. Purcell \& Rebecca D. Eckert (2006). Journal for the Education of the Gifted. Describing the Status of Programs for the Gifted. A Call for Action. Volume: 40 issue: 1, page(s): 20-49.

11. Karen B. Rogers (2007). Lessons Learned About Educating the Gifted and Talented. A Synthesis of the Research on Educational Practice. Gifted Child Quarterly. Volume: 51 issue: 4, page(s): 382-396.

12. Jarvis, Jane M \& Henderson, Lesley (2014). Defining a coordinated approach to gifted education. Australasian Journal of Gifted Education. Vol. 23, No. 1, Jun 2014: 5-14

13. Panfilova V.M., Panfilov A.N., Merzon E.E. Organizational-Pedagogical Conditions to Form the Foreign Competence in Students with the Features of Linguistic Giftedness // International Education Studies; Vol. 8, No. 2; 2015: 176-185.

14. Begabte Kinder finden und fördern. Ein Wegweiser für Eltern, Erzieherinnen und Erzieher, Lehrerinnen und Lehrer. Bundesministerium für Bildung und Forschung, 2015. 120 p.

15. Trubaychuk L.V. Phenomenology of giftedness development among the children of preschool age: Monograph. Moscow: Balass, 2010. 182 p. 
16. Schlichte-Hiersemenzel B. $\mathrm{Zu}$

Entwicklungsschwierigkeiten hoch begabter Kinder und Jugendlicher in Wechselwirkung mit ihrer Umwelt. Erfahrungen und mögliche Lösungswege. Studie im Auftrag des Bundesministeriums für Bildung und Forschung. Februar 2001. 54 p.

17. Kirsi Tirri \& Elina Kuusisto (2013). How Finland Serves Gifted and Talented Pupils. Journal for the Education of the Gifted. Volume: 36 issue: 1, page(s): 84-96.

18. The working concept of giftedness. M.: IPE "Magister", 1998. 68 p.

19. Order of RF Ministry of Education and Science No. 1897 "On the approval of the federal state educational standard of basic general education" issued on December 17, 2010. - URL http://base.garant.ru/55170507/

20. V.A. Domansky. Culturological bases of literature study at school: Dis. by Dr. of ped. sciences. Tomsk, 2000. 403 p.

21. Glukhova V.A. Social-psychological factors of a child creative giftedness development // Bulletin of the South Ural State University; Series "Psychology". Issue 5. 2009. No. 18 (151). pp. 49-53. 